\title{
An Unique Shell Gorget from Wood County, Texas
}

Jesse Todd

Unknown

Follow this and additional works at: https://scholarworks.sfasu.edu/ita

Part of the American Material Culture Commons, Archaeological Anthropology Commons, Environmental Studies Commons, Other American Studies Commons, Other Arts and Humanities Commons, Other History of Art, Architecture, and Archaeology Commons, and the United States History Commons

Tell us how this article helped you.

This Article is brought to you for free and open access by the Center for Regional Heritage Research at SFA ScholarWorks. It has been accepted for inclusion in Index of Texas Archaeology: Open Access Gray Literature from the Lone Star State by an authorized editor of SFA ScholarWorks. For more information, please contact cdsscholarworks@sfasu.edu. 


\section{An Unique Shell Gorget from Wood County, Texas}

Creative Commons License

(c) (i) (8)

This work is licensed under a Creative Commons Attribution-NonCommercial 4.0 International License 


\section{An Unique Shell Gorget from Wood County, Texas}

\section{Jesse Todd}

During the excavations preceding the construction of Lake Fork Reservoir, archaeologists from Southern Methodist University uncovered a child's burial at the Gilbreath site (41WD538) in Wood County, Texas (Bruseth and Perttula 1981:16). The child was from 2 to 3 years of age and burial furniture consisted of five ceramic vessels and an unique marine shell (Busycon sp.) gorget from the chest area (Figure 1). The age of the site, which has a Titus phase component, ranges from ca. A.D. 1430-1680.

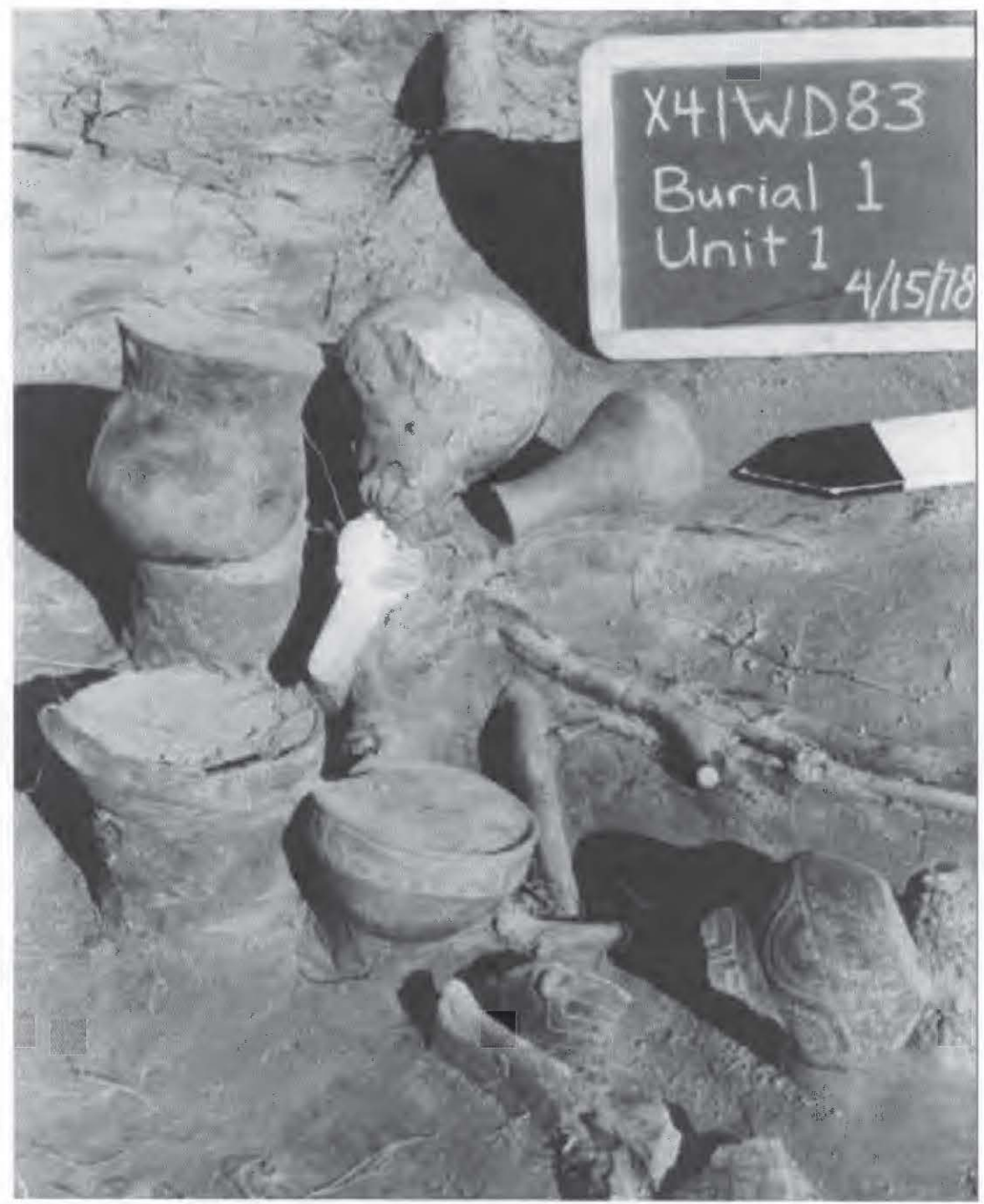

Figure 1. Close-up of shell gorget in child's burial at the Gilbreath site (41WD538). Photograph courtesy of Southern Methodist University. 
Conch shell gorgets are not abundant in Caddo archaeological sites in Northeast Texas. Two sites along the Red River, the Sanders site (4ILR2, Krieger 1946) in Lamar County, and the Roitsch site (41RR 16, Harris 1953; Skinner et. al. 1969) in Red River County, contain almost all of the shell gorgets found in Northeast Texas. Seventeen gorgets were discovered at the Sanders site (Jackson et al. 2000) and five were recovered from the Roitsch site.

The gorget from the Gilbreath site (Figure 2) is $109.6 \mathrm{~mm}$ long and $53.6 \mathrm{~mm}$ wide at its widest point. It is $4.0 \mathrm{~mm}$ thick, and the two perforations are approximately $5.5 \mathrm{~mm}$ in diameter. The gorget is highly polished and the lower end appears to have been utilized for some unknown purpose because of the amount of wear present along its edges. The gorget has the shape of a mace similar to engravings found on shell cups at the Craig Mound at the Spiro site in eastern Oklahoma (Phillips and Brown 1978).

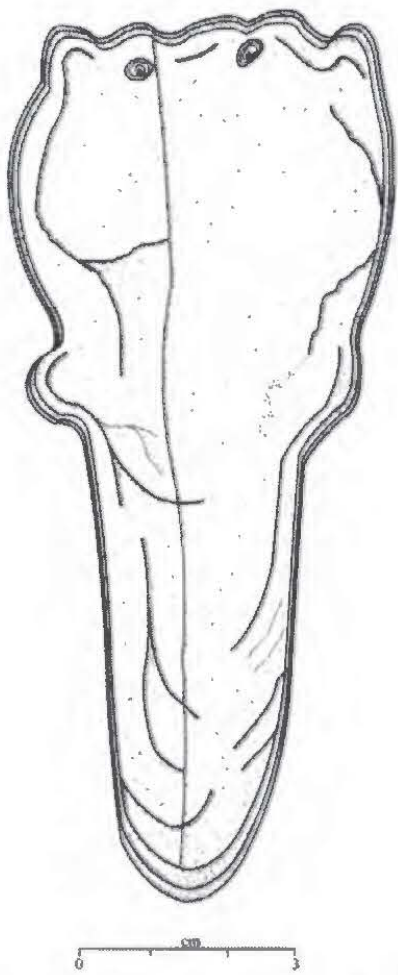

Figure 2. Shell gorget from the Gilbreath site.

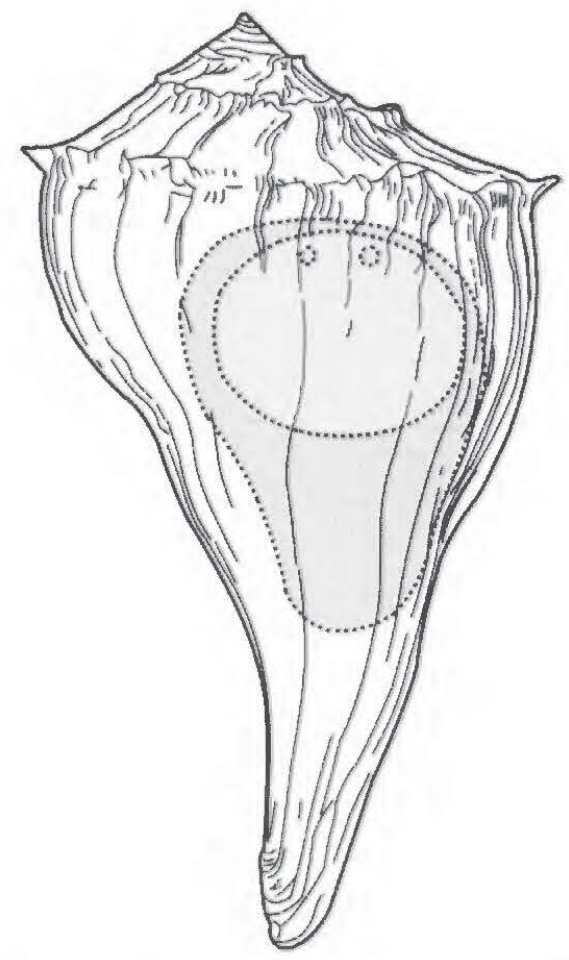

Figure 3. Locations on a Busycon shell that are used in making gorgets (modified from Holmes 1883:Plate 29).

The location on the Busycon shell that the gorget came from is interesting. Most gorgets made by Native Americans came from the shell's outer whorl (Figure 3). However, this gorget appears to have been made from the lower portion of a Busycon shell, which is usually the part that was used to make celts (Figure 4).

\section{ACKNOWLEDGEMENTS}

I would like to thank Dr. Mike Adler at Southern Methodist University for providing the gorget for analysis and Dr. Timothy Perttula for his help on this article. In addition, Lance K. Trask did the illustrations. 


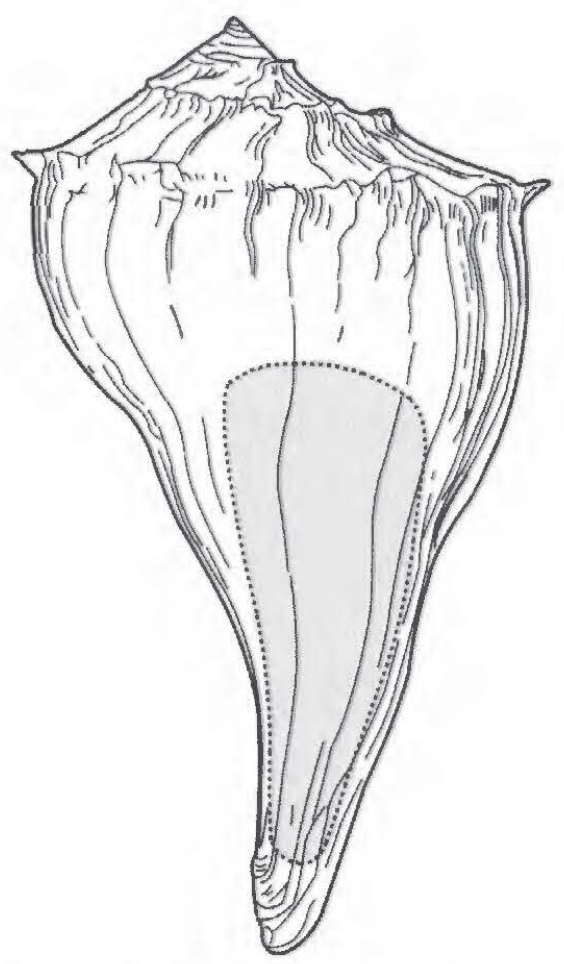

Figure 4. Location of the portion of a Busycon shell used in making shell celts (modified from Holmes 1883:Plate 29).

\section{REFERENCES CITED}

Bruseth, James E. and Timothy K. Perttula

1981 Prehistoric Settlement Patterns at Lake Fork Reservoir. Texas Antiquities Series, Report No. 2. Southern Methodist University, Dallas, and Texas Antiquities Committee, Austin.

Harris, R. King

1953 The Sam Kaufman Site, Red River County, Texas. Bulletin of the Texas Archeological Society 24:43-68.

Holmes, William B.

1883 Art in Shell of the Ancient Americans. In The Second Annual Report of the Bureau of Ethnology to The Secretary of the Smithsonian Institution, 1880-1881, pp. 179-305. Government Printing Press, Washington, D.C.

Jackson, A. T., Marcus S. Goldstein, and Alex D. Krieger

2000 The 1931 Excavations at the Sanders Site, Lamar County, Texas: Notes on the Fieldwork, Human Osteology, and Ceramics. Archival Series 2. Texas Archeological Research Laboratory, The University of Texas at Austin.

Krieger, Alex D.

1946 Culture Complexes and Chronology in Northern Texas with Extension of Puebloan Datings to the Mississippi Valley. Publication No. 4640. The University of Texas at Austin. 
Phillips, Phillip and James A. Brown

1978 Pre-Columbian Shell Engravings from the Craig Mound at Spiro, Oklahoma, Part I. Peabody Museum of Archaeology and Ethnology, Harvard University Press, Cambridge, Massachusetts.

Skinner, S. Alan, R. King Harris, and Keith M. Anderson (editors)

1969 Archaeological Investigations at the Sam Kaufman Site, Red River County, Texas. Contributions in Anthropology No. 5. Department of Anthropology, Southern Methodist University, Dallas. 